\title{
RECONSTRUCTION OF INDONESIAN LABOUR REGULATION TO THE INTERESTS WORKERS IN INDONESIA \\ (Reviewing About Salary)
}

\author{
Budiyono \\ Semarang Advocates \\ budiyono061970@gmail.com
}

\begin{abstract}
Workers protection is intended to guarantee the basic rights of workers and ensure equality of opportunity and treatment without discrimination on any basis whatsoever for the welfare of workers and their families with regard to the progress of the business world. In Part Two of Article 88 of Act No. 13 of 2003 which regulates the Wage has been set that the government set a wage policy that protects workers in Article 88 paragraph (2) with the hope of every worker is entitled to the income that meets a decent livelihood for humanity in Article 88 paragraph (1). As for the wage to protect workers in question consists of a minimum wage, wages overtime, wages do not work due to absent, wages do not work due to other activities outside of work, wages for exercising the right to take a rest, shape and manner of payment of wages, Fines and deductions from wages, things that can be accounted for by wages, wage structure and scale proportionally, wages for severance payments and wages for income tax calculation.
\end{abstract}

Keywords: Protection; regulation. Workers;

\section{A. INTRODUCTION}

Republic of Indonesian Regulation Number 13 of 2003 on Labour/Workers has been enacted in Jakarta on March 25, 2003 in the era of Megawati Soekarno Putri. The dynamics of economic globalization which increasingly advanced today ${ }^{1}$, pushing all countries in all over the world continue to run fast in reforming all of its economic policies, formation of the Act on the basis that national development carried out in the framework of human development in Indonesia and Indonesian society to create a society that is prosperous, just,

\footnotetext{
${ }^{1}$ I. Gusti Ayu Ketut Rachmi Handayani, Edi As'Adi, Guntur Hamzah, Tommy Leonard, Gunarto, Relationship between Energy Consumption in International Market and Indonesia Prices Regulation, International Journal of Energy Economics and Policy, 2017, 7(5), 9-15.
}

prosperous, equitable, both material and spiritual, based on Pancasila and the Constitution of the Republic of Indonesia of $1945^{2}$.

Besides, in his judgment also stated that in the implementation of national development, workers has the role and position are very important as the actors and development objectives so that in accordance with the role and position of workers, required manpower development to improve the quality of the workforce and his participation in development as well as increased protection workers and their families in accordance with human dignity 3 .

2 Widodo Muktiharjo, 2014, Building Enterprises with strength Image, Yuma Library, Surakarta, p.67

3 Directorate Terms Of Employment, 2003, Act. No. 13 of 2003, Jakarta 
Workers protection is intended to guarantee the basic rights of workers and ensure equality of opportunity and treatment without discrimination on any basis whatsoever for the welfare of workers and their families with regard to the progress of the business world.

In Part Two of Article 88 of Act No. 13 of 2003 which regulates the Wage has been set that the government set a wage policy that protects workers in Article 88 paragraph (2) with the hope of every worker is entitled to the income that meets a decent livelihood for humanity in Article 88 paragraph (1) ${ }^{4}$.

As for the wage to protect workers in question consists of a minimum wage, wages overtime, wages do not work due to absent, wages do not work due to other activities outside of work, wages for exercising the right to take a rest, shape and manner of payment of wages, Fines and deductions from wages, things that can be accounted for by wages, wage structure and scale proportionally, wages for severance payments and wages for income tax calculation.

The purpose of the regulation on remuneration in the Workers Law is actually very beneficial to provide protection for workers, but the maker of Law is still not wholeheartedly for in chapter others determine their suspension of earnings if the company and / or the employer is able to meet the wage has been decided by the government.

Despite the suspension of wage ordinances also regulated by the government, but of course this makes the actual regulations aimed at both be biased and vague that ultimately the workers / seek out the victims of these provisions.

4 Jacob Lukman, 2014, Astra on Becoming Pride of the Nation, PT. Gramedia, Jakarta according to Aristotle's theory, justice will be felt when the relevant system in the basic structures of a well-ordered society, political, economic and social institutions are satisfactory in relation with the concept of stability and balance. ${ }^{5}$

\section{B. DISCUSSION}

Basically in the business world either owned (BUMN), regional property (enterprises), belonging to the private and individual property relations between employers and workers are the same as forprofit, achieving the targets set for the sake of full filled rights and obligations, and if likened to the relationship between employers and workers like two sides of a coin, though different side but they always go hand in hand anywhere and everywhere. Employers want the efforts of developed and developing as well as workers / unions also want their work can be sustainable so that it can meet their needs and meet their family needs.

Nonetheless, the fact that employers will be more powerful and flexible in managing its business including setting policies related to workers, employment and other provisions related to the Industrial Relations which contains rights and obligations of workers.

Act. No. 13 of 2003 on Workers seeks to regulate and protect the two sides both employers and workers. The rights and obligations of each party as a whole has been regulated in the Law. Likewise, the presence of the State through agencies or institutions in the field of employment has

${ }^{5}$ Anis Mashdurohatun, Redyanto Sidji, Gunarto and Mahmutarom, Factors Causing Banking Cyber Crime in Indonesian, International Journal of Economic Research, Volume 14 Number 15 2017. P.295 
also been accommodated within the provisions of the Act.

Workers Law has required provision of the Trade Union ${ }^{6}$ / Workers Union in companies that have workers more than ten people are allowed to form Trade Unions / Workers refers to the Law related namely Act. No.21 of 2000 on the Trade Union / Workers Union. Such provision is clearly provide a space for workers to freedom of assembly and association with the aim to accommodate all forms of aspiration the Industrial Relations?.

Other provisions in the Workers Law also stipulates that the Collective Workers Agreement (CLA) made between employers and representatives of workers who are more detailed agreements on the rights and obligations of each party are not yet regulated in Law detail. However, if in a company there are no trade unions / workers unions, employers are required to make the Company Regulations containing the provisions of the rights and obligations of workers to be registered with the agency or agencies in the field of employment, and therefore the rights and obligations of workers never mind very clearly arranged either in the Law, Collective Workers Agreement (CLA) as well as in the Company Regulations (PP).

Material or content in the Collective Workers Agreement (CLA) as well as in the Company Regulations (PP) if it was contrary to the Act, as stipulated in Act. No. 13 of 2003 on Workers declared null and void and will apply the provisions of the Act, while if there is a higher provision of Law then used is more favorable to workers ${ }^{8}$.

In this paper the substance to be analyzed is the provision in the Act relating to remuneration, as regulated in Article 88 of Act. No. 13 of 2003 on the whole labour reads as follows:

\section{Article 88}

(1) Every worker is entitled to earn a living befitting meet humanity.

(2) To realize the income that meets a decent livelihood for humanity as referred to in paragraph (1), the government established a wage policy that protects workers.

(3) Wage policy that protects workers as referred to in paragraph (2) shall include:

a. minimum wage;

b. overtime;

c. wages do not work due to absent;

d. wages do not work due to other activities outside of work;

e. wages for exercising the right to take a rest;

f. form and manner of payment of wages;

g. fines and deductions from wages;

h. things that can be calculated with wages;

i. the structure and scale of remuneration proportional;

j. wages for severance payments; and

k. wages for income tax calculation.

(4) The government set the minimum wage referred to in paragraph (3) a decent living based on the needs and with due regard to productivity and economic growth.
6 Act No. 21 of 2000, the Trade Union / Workers

7 Aldilla D. Wijaya, 2015, Never Give Up, Qultumedia, Jogjakarta
8 Christian Orchard, 2016, Towards Professionalism Plantation State Owned Company, Gramedia Group, Medan. 
The provisions referred to in Article 88 proceed with the provisions of Article 89, which reads:

(1) The minimum wage referred to in Article 88 paragraph (3) letter a can consist of:
a. minimum wage based on the province or regency / city;
b. minimum wage by sector in the province or district / city.

(2) The minimum wage referred to in paragraph (1) is directed towards meeting the need for decent living.

(3) The minimum wage referred to in paragraph (1) shall be determined by the Governor with regard to the recommendation of Provincial Wage Council and / or the Regent / Mayor.

(4) Components as well as the implementation phases of achieving decent living requirements referred to in paragraph (2) shall be regulated by the Minister.

While the remaining provisions in Article 90 of the Workers Law provides that ${ }^{9}$ :

(1) Employers are prohibited from paying wages lower than the minimum wage referred to in Article 89.

(2) For those entrepreneurs who can not afford to pay the minimum wage referred to in Article 89 to do the suspension.

(3) The procedure for the suspension referred to in paragraph (2) shall be regulated by the Minister.

Government Regulation No. 78 Act. 2015 on Equal Remuneration, signed by the President on 23 October 2015 and entered into force immediately, regulate important matters, among others:

1. Income Eligible

A decent income to meet the needs of herself and her family live reasonably be accepted by the workers from their work. A decent income consists of wages and non-wage income.

\subsection{Wage}

Wages consisting of components: wages without benefits, or the basic salary and fixed allowance, or basic salary, fixed allowances, and allowances are not fixed.

a. Wages without benefits Wage without allowances which amount of money received by the worker or workers permanently. Example: A worker working at Company $A$ to get a net wage of Rp. 2.500.000, - in which the wage scale is used as the basis for calculating THR, overtime, severance pay, social security contributions, and others.

b. Principal Wages and Benefits Permanent

Basic wage is the base remuneration paid to workers according to the level or type of work, which amount is determined based on an agreement between workers and employers.

While the Fixed Allowance is a payment to workers are done regularly and is not associated with the presence of workers or achievement of certain work. 
If components of the remuneration given to workers consists of Basic Wages and Benefits Still, the magnitude of the Basic Wage of at least $75 \%$ of the total wages and allowances Fixed Principal.

Example: A worker Company $\mathrm{B}$ received a wage of Rp. 2.000.000, - consisting of wages and allowances Fixed Principal. Then Principal minimum wage is $75 \% \times \mathrm{Rp}$. 2.000.000, - = 1.500.000, -.

c. Basic wages, benefits Fixed and Variable Benefit

Variable allowances are payments directly or indirectly related to workers, given on an intermittent basis, paid by units of time are not the same as time payments for basic wages. Examples: transportation and food allowance paid based on attendance.

The amount of the basic wage is the same as above, ie at least $75 \%$ of the wages and allowances Fixed Principal.

For example: a worker working on PT C for a wage of Rp. 2.500.000, - where the value of the Rp. 500,000 , - a meal and transport money. Then the amount of wages Principal is $75 \% \times$ (Rp. $2,500,000$ - Rp. 500,000) = Rp. 1.500 .000 , - and his regular allowance of Rp. 500.000, -.

\subsection{Non-wage income}

Revenue Non wages given to workers are in the form of Allowance (THR) religious, and can also be added in the form of bonuses on profits of enterprises, money substitutes working facilities and or services in a particular business (hotel business and the restaurant business in hospitality).

THR must be provided by the company and shall be paid no later than seven days before the feast.

The company can also provide working facilities of facilities / equipment which is provided for a particular office or employment or to the workers such as facility vehicles, vehicle pickup, or a free meal.

If such facilities were not available or insufficient, the company can replace it with a substitute cash working facilities. Money service in the hotel business and the restaurant business in the hospitality shall be distributed to the workers after deducting the risk of loss or damage and utilization of human resources quality improvement.

\section{Minimum wage}

Minimum wages are set by the Governor each year based on the needs of decent living and having regard to productivity and economic growth, as a safety net, which is the lowest monthly wage which consists of wages without benefits or basic wage including benefits.

The minimum wage applies only to workers with tenure of less than one year on the company concerned. Wages for workers who have worked one year or more negotiated between workers with employers.

The formula for calculation of the minimum wage as follows: 
t)\}

$$
\mathrm{UMN}=\mathrm{UMT}+\{\mathrm{x}(\mathrm{t}+\% \text { GDP Inflation }
$$

Where:

UMN = Minimum wage to be set.

UMT = Minimum Wage current year.

Inflation $\mathrm{t}=$ inflation calculated from

the period of September last year up to September period of the current year.

GDP $\mathrm{t}=$ Growth in gross domestic product, calculated on the Gross Domestic Product growth covering the period Quarter III and IV the previous year and Quarter I and II of the current year.

3. Overtime Wages

Overtime wages must be provided by employers employing workers to work overtime or on weekly rest, or employed on an official holiday, as compensation to the worker in accordance with the provisions of the legislation.

4. Forms and Payment Wages

Wage determination

Wages are set by

Unit Time: Daily, weekly, monthly; and / or

Unit Results: according to the results of the work that has been agreed.

If wages are paid on a daily, calculation of wages:

Working time 6 days a week, Wages Day = Wages 1 month: 25 .

Working time 5 days a week, Wages Day = Wages 1 month: 21.

Wage Payment Method

Fastest payment of wages once a week or once a month at the latest unless the employment agreement for less than 1 week.

Payment of wages must use the currency. Payment of wages can be directly or bank transfer.

5. Things that can be imputed to Wages
Things that can be calculated with wages consist of: fine, compensation, wage cuts to a third party, an advance of wages, rent and / or lease of goods belonging to the company that leased by the employer to the worker / workers, debt or mortgage debt workers to entrepreneurs, and / or excess payment of wages.

6. Remuneration Structure and Scale Proportionally

Structure and Wage Scale for the purpose of:

realizing equitable wage;

encourage increased productivity in the Company;

improve the welfare of employees / workers; and

ensure certainty and reduce the wage gap between the highest and lowest wages.

Wage Structure and Scale obligatory structured by entrepreneurs with regard classification, job title, length of employment, education, and competency. Further Wage Structure and Scale shall be notified to all employees / workers.

7. Wages for Severance Payments

Components of wages as the basis for calculating severance consists of basic salary and fixed allowance. In the event that the employer provide wages to workers without allowances, severance calculation basis is the wages received by workers. Severance payment provisions:

If income is calculated daily, earnings per month $=30 x$ the daily income.

If earnings are calculated based on the unit results, pieces / bulk, or commission, the daily income $=$ average earnings per day during the last 12 
months and should not be less than the UMP / MSE.

If the work depends on the weather and the wage contract, the calculation of the monthly wage = average wage last 12 months.

Both provisions of the Workers Law and Government Regulation No. 78 on Equal Remuneration seen of 2015 is sufficient to provide protection for workers. However, when looking at the provision of Article 90 paragraph (2) "For entrepreneurs who can not afford to pay the minimum wage referred to in Article 89 to do the suspension" to make wage protection for workers raw back.

Workers has always been a sensitive issue each year. For employers, the wage itself is costs are minimized as much as possible to obtain maximum benefits. As for the workers, they demanded to be given a decent wage to ensure its survival.

Suspension Procedures The minimum wage stipulated in the Ministerial Decree No. KEP-231 / MEN / 2003 of 2003 on the Procedure for Suspension of Minimum Wage. Employers who can not afford to pay the minimum wage can apply for the suspension of the minimum wage to the Governor through the government agency responsible for province employment ${ }^{10}$ no later than 10 days before the date of entry into force of the minimum wage. The petition is the result of a written agreement between employers and workers or union / workers record.

Under these provisions, it is clear that in order to be able to apply for suspension of UMK, employers must

10 Marcus Buckingham and Curt Coffman, 2017, First, Break All the Rules, Alfabet Library Group, Jakarta, p.37-38 reach an agreement with the workers/employees in relation to the suspension of the minimum wage.

If it has reached an agreement on the suspension of the minimum wage, then the next step is to deliver the petition to the Governor. For suspension of the minimum wage must be accompanied by: (1) the original manuscript written agreement between the employer and union / workers union or workers of the enterprise; (2) the company's financial statements consisting of balance sheet, the calculation of loss / gain along with explanations for two (2) years; (3) a copy of the certificate of incorporation; (4) the wage data by office workers; (5) the number of workers entirely and the number of workers who petitioned for the suspension of the implementation of the minimum wage; and (6) the development of production and marketing for 2 (two) years, as well as the production and marketing plan for two (2) years to come.

If the company applying for the suspension of the minimum wage is a legal entity, or if the governor felt the need for proof of financial inability of the company, the financial statements must be audited by a public accountant.

The application for suspension of the minimum wage, the governor will give approval or rejection after receiving suggestions and considerations Provincial Wage Council. If the minimum wage deferral is approved, the governor gave the suspension of the minimum wage for a maximum period of 12 months.

Related to the elucidation of Article 90 paragraph (2) of the Manpower Law, the Constitutional Court in its decision No. 72 / PUU-XIII / 2015 states that the phrase "... but is not obliged to pay the 
fulfillment of the minimum wage in effect at the time given the suspension" is inconsistent with the Constitution 1945 and does not have binding legal force. That is, the Court affirms the difference between the minimum wage payment deficiency during the suspension period remains to be paid by the employer ${ }^{11}$.

In other words, the suspension of payment of minimum wages by employers to workers are not necessarily eliminate the employer's obligation to pay the difference in minimum wages during the suspension period. Difference in unpaid minimum wages during the period of suspension is a businessman debt to be paid to the workers.

From the above description despite the suspension of minimum wage has been set by the Government, but the existence of Article 90 paragraph (2) of Act No. 13 of 2003 which opened up opportunities efforts of suspension of earnings this causes a lack of legal certainty against wage for workers. Previous article, Article 88 and Article 89 of the Workers Law that has been firmly set on wages weakened by the provision in Article 90 paragraph (2) Workers Law.

\section{CONCLUSION}

If the government wants to really protect workers in terms of wages must be firm because the bargaining position of workers in a weak position due to a lack of jobs, the authority of the employer to rationalize the workforce, the enforcement of sanctions is still not up to full interest, the reasons employers could shut down if forced to pay wages in accordance with provisions and others while the workers are very afraid of losing livelihood / job.
Right In order to properly protect the interests of workers that the provisions of Article 90 paragraph (2) of the wage deferral opportunities their efforts in Act No. 13 of 2003 on Workers needs to be revisited, even more precisely if omitted because in addition contradiction with the provisions of foregoing Articles also provide a justification for the employer to not pay the minimum wage.

While the minimum wage mandated by the Workers Law is the lowest wage and become a safety net for workers who have a working period of less 1 (one) year why should bargained by employers to make efforts suspension of earnings. Employers can do a corporate action to tackle the problem of remuneration intended for example to improve efficiency in the nonproduction sector, raise the price of production, and other measures so as to fulfill the obligation of payment of wages to workers yet maintain the viability of the company.

11 Suteki, 2018, Legal Research Methodology, Rajawali Press, Depok, p.129 


\section{BIBLIOGRAPHY}

Aldilla D. Wijaya, 2015, Never Give Up, Qultumedia, Jogjakarta Anis Mashdurohatun, Redyanto Sidji, Gunarto and Mahmutarom, Factors Causing Banking Cyber Crime in Indonesian, International Journal of Economic Research, Volume 14 Number 15 2017.

Christian Orchard, SH, MKn, 2016, Towards Professionalism Plantation State Owned Company, Gramedia Group, Medan.

I. Gusti Ayu Ketut Rachmi Handayani, Edi As'Adi, Guntur Hamzah, Tommy Leonard, Gunarto, Relationship between Energy Consumption in International Market and Indonesia Prices Regulation, International Journal of Energy Economics and Policy, 2017, 7(5).

Directorate Terms Of Employment, 2003, Act. No. 13 of 2003, Jakarta Jacob Lukman, 2014, Astra on Becoming Pride of the Nation, PT. Gramedia, Jakarta

Marcus Buckingham and Curt Coffman, 2017, First, Break All the Rules, Alfabet Library Group, Jakarta

Suteki, 2018, Legal Research Methodology, Rajawali Press, Depok

Widodo Muktiharjo, 2014, Building Enterprises with strength Image, Yuma Library, Surakarta 